\title{
Carrier state of GBS in the aspect of perinatal antibiotic therapy in 2007-2011
}

\author{
Nosicielstwo GBS w aspekcie antybiotykoterapii okołoporodowej w latach 2007-2011
}

\author{
Sławomir Szymański ${ }^{1 凶}$, Katarzyna Szczerba ${ }^{2}$, Violetta Konstanty-Kurkiewicz ${ }^{3}$, Witold Malinowski ${ }^{1}$, \\ Olimpia Sipak-Szmigiel ${ }^{1}$
}

${ }^{1}$ Pomorski Uniwersytet Medyczny w Szczecinie, Zakład Położnictwa i Patologii Ciąży, ul. Żołnierska 48, 71-210 Szczecin

Pomeranian Medical University of Szczecin, Department of Obstetrics and Pathology of Pregnancy

${ }^{2}$ Regionalny Szpital w Kołobrzegu, Oddział Ginekologiczno-Położniczy, ul. Łopuskiego 31-33, 78-100 Kołobrzeg

Regional Hospital in Kołobrzeg, Department of Obstetrics and Gynaecology

${ }_{3}^{3}$ Pomorski Uniwersytet Medyczny w Szczecinie, Klinika Położnictwa i Ginekologii, al. Powstańców Wlkp. 72, 70-111 Szczecin

Pomeranian Medical University in Szczecin, Department of Obstetrics and Gynaecology

sszymanski@o2.pl

\begin{abstract}
Introduction: A significant decline in the proportion of the perinatal mortality of foetuses and newborns has been observed in recent years. The use of perinatal antibiotic therapy in order to reduce the risk of infection, including strains of group B Streptococcus (GBS) - Streptococcus agalactiae contracted during birth, is one of the reasons for this outcome.

Materials and methods: Material for the study was obtained from medical record data covering 1,328 live births of individual infants and their mothers. The analysed continuous parameters are described with appropriate numbers, arithmetic mean, standard deviation, and median, minimum and maximum values. Discrete parameters (qualitative) are expressed as percentages (fractions). The arithmetic means between groups were compared using Student's t-test. For analysis of fractions the $\chi^{2}$ test was used with the Yates correction (for a small number of cells). The level of statistical significance was accepted at $\mathrm{p}<0.05$
\end{abstract}

Results: The mean age of women giving birth was estimated at $27.5 \pm 5.1$ years. The mean duration of pregnancy was $39.2 \pm 1.6$ weeks. The mean time from the rupture of the amniotic sac to completion of birth was $352.2 \pm 925.2$ minutes. The total time of the childbirth of an infected newborn was significantly longer then the birth of a healthy newborn (453.3 vs 383.8; $p<0.0001$ ). The Apgar score was significantly higher in healthy newborns then in infected ones ( $9.3 \mathrm{vs} 8.6 ; \mathrm{p}<0.0001$ ). The percentage of treated pregnant women scored $26.81 \%$, while those with a positive culture was $78.43 \%(\mathrm{p}<0.0001)$.

Conclusions: The use of perinatal antibiotic prophylaxis reduces the incidence of early GBS infections in newborns. The use of perinatal antibiotic therapy in the absence of GBS culture is not a common procedure. However, by comparing years 2007-2011, it is practiced more and more. The occurrence of the GBS carrier state is common.

Keywords: carriers of GBS; infection; childbirth; antibiotic.

\begin{abstract}
ABSTRAKT
Wstęp: W ciągu ostatnich lat obserwowane jest wyraźne obniżanie się odsetka umieralności okołoporodowej płodów i noworodków. Jedną z przyczyn takiego stanu jest zastosowanie okołoporodowej antybiotykoterapii celem zmniejszania ryzyka zakażenia okołoporodowego m.in. szczepami paciorkowca grupy B (GBS) - Streptococcus agalactiae.

Materiały i metody: Materiał do badań stanowiły uzyskane z historii chorób dane 1328 żywo urodzonych, pojedynczych noworodków i ich matek. Badane parametry ciągłe opisano, podając odpowiednią liczebność, średnią arytmetyczną, odchylenie standardowe, medianę oraz najmniejszą i największą wartość. Parametry dyskretne (jakościowe) przedstawiono jako odpowiednie procenty (frakcje). Średnie arytmetyczne między grupami porównano testem t-Studenta. Do analizy frakcji użyto testu $\chi^{2}$, także z poprawką Yatesa (dla małych liczebności komórek). Poziom istotności statystycznej przyjęto dla $\mathrm{p}<0,05$ Wyniki: Średni wiek rodzących wyniósł 27,5 $\pm 5,1$ lat. Średni czas trwania ciąży wyniósł $39,2 \pm 1,6$ tygodnia ciąży. Średni
\end{abstract}

czas od pęknięcia pęcherza płodowego do zakończenia porodu wyniósł 352,2 $\pm 925,2 \mathrm{~min}$. Całkowity czas porodu noworodka zakażonego był istotnie dłuższy od czasu porodu noworodka zdrowego (453,3 vs 383,8; $p<0,0001$ ). Stan urodzeniowy noworodka oceniany wg punktacji w skali Apgar był istotnie wyższy u noworodków zdrowych niż u noworodków zakażonych (9,3 vs 8,6; p < 0,0001). Odsetek leczonych ciężarnych wyniósł $26,81 \%$, natomiast tych $\mathrm{z}$ dodatnim wynikiem posiewu tylko $78,43 \%$ (p = 0,0001).

Wnioski: Zastosowanie okołoporodowej profilaktyki antybiotykowej (IAP) ma wpływ na zmniejszenie częstości występowania wczesnych infekcji GBS u noworodków. Stosowanie IAP w razie braku posiewu w kierunku GBS nie jest powszechną procedurą, jednakże w zestawieniu lat 2007-2011 coraz częściej praktykowaną. Występowanie nosicielstwa GBS jest powszechne.

Słowa kluczowe: nosicielstwo GBS; zakażenie; poród; antybiotykoterapia. 


\section{INTRODUCTION}

A decline in the proportion in the perinatal mortality of foetuses and newborns has been observed in recent years. Despite enormous progress made in the field of perinatal care, there is still a risk of infection of the foetus during pregnancy or childbirth. One of the main etiological factors responsible for this is streptococci. An increased occurrence of such bacteria in both the urogenital tract and the gastrointestinal system of pregnant women has been observed. This applies in particular to group B of Streptococcus (GBS) - Streptococcus agalactiae. Infection of this type can have a very dramatic course. For this reason, it is valid to introduce perinatal antibiotic prophylaxis (IAP) $[1,2]$. Therefore, nowadays intrapartum antibiotic prophylaxis has full medical justification. It was also confirmed that the costs associated with the prevention of GBS infections in newborns is much lower than the treatment of infected mothers or their children during labour. A growing number of perinatal infections, caused by group B streptococci, as well as the increasing incidence of bacterial strains with documented resistance mechanisms MLSB arouse anxiety among physicians. Thus, it is associated with an increased risk of serious infections in newborns. Therefore, in order to achieve full and reliable assessment, both benefits and risks arising from the widely used antibiotic prophylaxis, it is reasonable to conduct further research in this area.

\section{MATERIALS AND METHODS}

Material consisted of data obtained from the medical records of 1,328 newborn infants and their mothers. Deliveries took place at the Regional Hospital in Kołobrzeg in 2011 (the year of the introduction to the daily practice of PTG therapeutic guidelines for the prevention of GBS infections in newborns) and in 2007 (in the absence of widespread prevention of GBS infections in newborns). Statistical analysis was carried out using Statistica PL v. 10.0 StatSoft, USA. Parameters measured continuously were described with the appropriate numbers, arithmetic mean, standard deviation, and median and minimum and maximum values. Discrete parameters (qualitative) were expressed as percentages (fractions). Arithmetic means were compared between groups with the t-test.

\section{RESULTS}

The first table contains general information about women in labour.

The mean age of women giving birth was estimated at 27.5 \pm 5.1 years. The youngest woman was 16 years of age, while the oldest was 43 years old. The mean parity score reached 1.6 \pm 0.9 . Pregnancies were in most cases mature. The mean duration of pregnancy was $39.2 \pm 1$. 6 weeks. The shortest pregnancy lasted 27 weeks, the longest 43 weeks. The total mean time of birth was $387.9 \pm 193.5$ minutes. The mean time from rupture of the amniotic sac to completion of birth was $352.2 \pm 925.2$ minutes.

The second table contains general information about the newborn.

The mean Apgar score assessed in a newborn in the first minute was $9.2 \pm 1.2$ points. Newborn babies weighed on average $3381 \pm 523 \mathrm{~g}$. The lightest weighed $990 \mathrm{~g}$, the heaviest 5050 $\mathrm{g}$. The mean duration of hospitalization of a newborn after vaginal delivery was $3.9 \pm 2.7$ days, compared to $5.8 \pm 2.2$ days after birth through caesarean section.

Table 3 shows the correlation between the general parameters of the women in labour, childbirth and newborns in terms of early-symptomatic infections in the newborns.

The parity of the mothers of infected newborns was significantly lower than the parity of mothers of healthy ones

TABLE 1. General information related to women giving birth

\begin{tabular}{|c|c|c|c|c|c|}
\hline Parameters & n & Median & Mean \pm SD & Min. & Max. \\
\hline Age (years) & 1328 & 28 & $27.5 \pm 5.1$ & 16 & 43 \\
\hline Parity & 1328 & 1 & $1.6 \pm 0.9$ & 1 & 8 \\
\hline Duration of gestation (weeks) & 1328 & 39 & $39.2 \pm 1.6$ & 27 & 43 \\
\hline Total duration of labour (minutes)* & 1061 & 360 & $387.9 \pm 193.5$ & 34 & 1320 \\
\hline Total time from rupture of foetal membrane to delivery (minutes) ${ }^{\star *}$ & 1174 & 120 & $352.2 \pm 925.2$ & 1 & 24000 \\
\hline
\end{tabular}

n - size of studied population; SD - standard deviation; Min. - minimum value; Max. - maximum value

* refers to vaginal deliveries; ${ }^{* *}$ refers to all deliveries

TABLE 2. General data concerning newborns

\begin{tabular}{|c|c|c|c|c|c|}
\hline Parameters & $\mathbf{n}$ & Median & Mean \pm SD & Min. & Max. \\
\hline Evaluation of the newborn with the Apgar score & 1328 & 10 & $9.2 \pm 1.2$ & 1 & 10 \\
\hline Newborns' birthweight (g) & 1328 & 3400 & $3381 \pm 523$ & 990 & 5050 \\
\hline Hospitalization of newborns after vaginal delivery (in days) & 1064 & 3 & $3.9 \pm 2.7$ & 1 & 30 \\
\hline Hospitalization of newborns after caesarean section (in days) & 264 & 5 & $5.8 \pm 2.2$ & 3 & 23 \\
\hline
\end{tabular}

$\mathrm{n}$ - size of studied population; SD - standard deviation; Min. - minimum value; Max. - maximum value 
TABLE 3. General specifications for the women in labour, delivery and newborns with the occurrence of early-symptomatic infections in the newborns. Comparison of means

\begin{tabular}{|c|c|c|c|c|c|c|c|}
\hline \multirow{3}{*}{ Parameters } & \multicolumn{6}{|c|}{ Newborn } & \multirow{3}{*}{$p^{*}$} \\
\hline & \multicolumn{3}{|c|}{ uninfected } & \multicolumn{3}{|c|}{ infected } & \\
\hline & mean & SD & 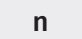 & mean & SD & $n$ & \\
\hline Maternal age (years) & 27.6 & 5.2 & 1240 & 27 & 4.9 & 88 & NS \\
\hline Parity & 1.6 & 0.9 & 1240 & 1.4 & 0.9 & 88 & $<0.02$ \\
\hline Duration of pregnancy (weeks) & 39.2 & 1.6 & 1240 & 39.4 & 1.8 & 88 & NS \\
\hline Hospitalization of newborn after vaginal delivery (in days) & 3.5 & 2 & 1000 & 10.8 & 3.4 & 64 & $<0.0001$ \\
\hline Hospitalization of newborn after caesarean section (in days) & 5.4 & 1.6 & 240 & 9.6 & 3.4 & 24 & $<0.0001$ \\
\hline Total duration of labour (minutes)** & 383.8 & 192.9 & 1059 & 453.3 & 193 & 64 & $<0.005$ \\
\hline Total time from rupture of foetal membrane to delivery (minutes)*** & 347.3 & 769.2 & 1163 & 629.4 & 2806 & 73 & $<0.02$ \\
\hline Evaluation of the newborn with the Apgar score & 9.3 & 1.2 & 1240 & 8.6 & 1.4 & 88 & $<0.0001$ \\
\hline
\end{tabular}

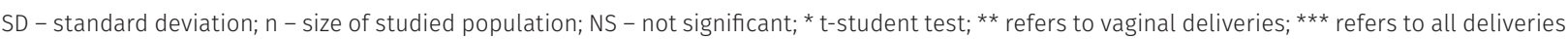

(1.4 vs 1.6). The duration of hospitalization of an infected infant who was born vaginally was significantly longer than the duration of the hospitalization of a healthy one (10.8 vs 3.5). The length of the hospital stay of an infected infant who was born by caesarean section was significantly longer than the duration of the hospitalization of a healthy newborn ( 9.6 vs 5.4). The total time of childbirth of an infected infant was significantly longer than the time of birth of a healthy child (453.3 vs 383.8). The total time of a childbirth of an infected infant was significantly longer than the time of birth of a healthy newborn (453.3 vs 383.8). The health status of an infant evaluated by the Apgar score was significantly higher in healthy newborns when compared to infected infants ( 9.3 vs 8.6). Comparisons of other parameters did not show statistical differences.

Table 4 shows the frequency of GBS strains detected in women who had a vaginal and anal swab for these bacteria prior to the delivery.

In 484 patients a smear was performed to detect GBS between 35-37 weeks of pregnancy. 331 pregnant women (68.39\%) were GBS negative, while 153 (31.61\%) were GBS positive.

Table 5 presents the frequency of perinatally used antibiotics in relation to GBS carriers.

Among all pregnant women participating in the study, 73.19\% did not receive perinatal antibiotic therapy, while $26.81 \%$ were
TABLE 4. Carriers of group B of Streptococcus (GBS) in pregnant women, in whom a swab from the vagina and the anus was taken between 35-37 weeks of pregnancy

\begin{tabular}{lcc}
\multicolumn{1}{c}{ Score of GBS in pregnant women } & $\mathbf{n}$ & $\%$ \\
\hline Positive & 153 & 31.61 \\
\hline Negative & 331 & 68.39 \\
\hline Total & 484 & 100 \\
\hline
\end{tabular}

$\mathrm{n}$ - size of studied population

treated. Among pregnant women without a smear for GBS, $77.01 \%$ were not treated with an antibiotic perinatally, while in $22.99 \%$ an antibiotic was introduced. Pregnant women with a negative GBS smear in $87.31 \%$ cases did not receive such treatment, but $12.69 \%$ were treated with an antibiotic perinatally. Whereas, $78.43 \%$ of pregnant women with a positive Pap GBS received antibiotics in the perinatal period, and $21.57 \%$ did not. Among all pregnant women treated perinatally with antibiotics, in $66.87 \%$ of cases GBS swabs were taken during pregnancy (29.73\% had negative results and $3.40 \%$ positive). The differences were statistically significant $(\mathrm{p}<0.0001)$.

Table 6 shows the incidence of perinatal antibiotic use in the studied years.

Women giving birth in 2007, in most cases did not receive antibiotics perinatally (90.15\%), while $9.85 \%$ were treated. In 2011, when the recommendations of the Polish Gynaecological

TABLE 5. Use of antibiotics and perinatal group B of Streptococcus (GBS) carrier status

\begin{tabular}{|c|c|c|c|c|c|c|c|c|c|}
\hline \multirow{3}{*}{$\begin{array}{c}\text { Treatment } \\
\text { of pregnant women }\end{array}$} & \multirow{2}{*}{\multicolumn{2}{|c|}{ Total }} & \multicolumn{6}{|c|}{ The result of GBS smear among pregnant women } & \multirow{3}{*}{$\begin{array}{l}\% \text { from the row } \\
\text { (the N) }\end{array}$} \\
\hline & & & \multicolumn{2}{|c|}{ no smear } & \multicolumn{2}{|c|}{ negative } & \multicolumn{2}{|c|}{ positive } & \\
\hline & $\mathrm{n}$ & $\%$ & n & $\%$ & n & $\%$ & n & $\%$ & \\
\hline Untreated & 972 & 73.2 & 650 & 77.01 & 289 & 87.31 & 33 & 21.57 & $66.87 / 29.73 / 3.40$ \\
\hline Treated & 356 & 26.8 & 194 & 22.99 & 42 & 12.69 & 120 & 78.43 & $54.49 / 11.80 / 33.71$ \\
\hline Total & 1328 & 100 & 844 & 100 & 331 & 100 & 153 & 100 & $63.55 / 24.92 / 11.52$ \\
\hline
\end{tabular}

$p^{*}<0.0001$

$n$ - size of studied population; * $X^{2}$ square test 
TABLE 6. The use of perinatal antibiotic therapy in pregnant women in the individual years

\begin{tabular}{|c|c|c|c|c|c|c|c|}
\hline \multirow{2}{*}{ Year of delivery } & \multicolumn{2}{|c|}{ Untreated pregnant } & \multicolumn{2}{|c|}{ Treated pregnant } & \multicolumn{2}{|c|}{ Total } & \multirow{2}{*}{$\begin{array}{l}\% \text { from the row } \\
\text { (the } \mathrm{N} \text { ) }\end{array}$} \\
\hline & $\mathrm{n}$ & $\%$ & $\mathbf{n}$ & $\%$ & $\mathrm{n}$ & $\%$ & \\
\hline 2007 & 651 & 66.94 & 71 & 19.94 & 722 & 54.33 & $90.15 / 9.85$ \\
\hline 2011 & 321 & 33.06 & 285 & 80.06 & 606 & 45.67 & $52.97 / 47.03$ \\
\hline Total & 972 & 100 & 356 & 100 & 1328 & 100 & $73.17 / 26.83$ \\
\hline
\end{tabular}

$p^{*}=0.0001$

$n$ - size of studied population; * $x^{2}$ square test

Association were in force, $52.97 \%$ of women in labour were covered by it, and $47.03 \%$ were not. Out of all pregnant women who did not receive antibiotic perinatally, $66.94 \%$ delivered babies in 2007 and $33.06 \%$ in 2011. From all pregnant women treated perinatally with antibiotics $19.94 \%$ of them had babies in 2007 and $80.06 \%$ in 2011. It has been observed that a perinatal antibiotic was used significantly more often in 2011 than in 2007 (47.03\% vs 9.85\%).

\section{DISCUSSION}

Falciglia et al. observed in their study that the incidence of early-symptomatic infections among newborn babies is 10 times higher in infants born prematurely [3]. Kraśnianin et al. noted that not only premature labour, but also a longer period from the moment of an interruption to the continuity of the membrane to completion of childbirth are associated with a higher risk of perinatal infection in the newborn. Moreover, they observed a higher incidence of early-symptomatic infections in infants born to younger mothers [4].

In our study we observed that the duration of pregnancy and the mean age of giving birth, both among healthy and infected infants, did not differ significantly. It was noted, however, that significantly more births of mothers of infected newborns were characterized by longer time elapsing from the start of rupture of the membrane to completion of delivery.

According to global epidemiological data, carriers of GBS in pregnant women is rated at $3-35 \%$ of respondents $[5,6,7$, $8,9,10]$. In Europe, the colonization of pregnant women by the streptococcus group B is around 6.6\% in Greece, 7\% in Spain and $16 \%$ in Germany [1]. According to Kraśnianin et al., every fifth woman in labour is a carrier of GBS strains [4].

On the basis of data published by several Polish centres, it can be said that in recent years there has been a clear upward trend in the number of women colonized by group B Streptococcus. Therefore, the increased numbers of neonates colonized by this bacterium has been recorded [1]. Kociszewska-Najman et al. evaluated the incidence of group B streptococcal colonization among Polish pregnant at 11.4\% [11]. However, in the study by Dobrowolska-Redo et al. the colonization of GBS was detected in as many as $40.9 \%$ of pregnant women [12].

In our research we found that among all women with vaginal and rectal swab testing for GBS taken between 35 and 37 weeks of pregnancy, $31.61 \%$ of them were colonized by Streptococcus group $\mathrm{B}$.
In a Glasgow et al. study, the group consisted of 130,447 fullterm single newborns and their mothers. Women gave birth in 19 hospitals in Utah, USA between 1998-2002. There was then a gradual increase in the frequency of the use of antibiotics perinatally among GBS carriers, from $75 \%$ in 1998 to $91 \%$ in 2002, and an increase of detection of GBS carriers during pregnancy from $1.9 \%$ in 1998 to $13.8 \%$ in 2002 [13].

In a retrospective analysis by Kociszewska-Najman et al., which covered 2,212 cases of birth in 2007 and 2008 in the Department of Obstetrics and Gynaecology, Medical University of Warsaw, antibiotics were used in $79.6 \%$ of GBS-positive women during labour. In the remaining $20.4 \%$ of GBS-positive pregnant women, for various reasons (hospital admissions in the second stage of labour, scheduled Caesarean section by preserved foetal membranes) perinatal antibiotics were not used [11].

In our study $78.43 \%$ of birth-giving carriers of GBS received perinatal antibiotic prophylaxis, and the percentage of treated carriers of GBS was significantly higher $(\mathrm{p}<0.0001)$ than the proportion of pregnant women treated perinatally with GBS negative or with an unknown GBS status. We observed that the increase in the frequency of perinatal antibiotic use in pregnant had a significant impact on a positive GBS result in swabs tests $(\mathrm{p}<0.0001)$. We also noted a clear increase in the frequency of perinatal antibiotic prophylaxis in 2011 (introduction of the daily practice of therapeutic guidelines for the prevention of GBS infections in newborn infants) compared to 2007 (no use; $\mathrm{p}=0.0001$ ).

\section{CONCLUSIONS}

1. Use of a perinatal antibiotic prophylaxis reduces the incidence of early-onset GBS infections in newborns.

2. Use of the above mentioned prophylaxis in the absence of GBS culture is not a common procedure, but in years 2007 and 2011 it was increasingly practiced.

3. The occurrence of the GBS carrier state is common.

\section{REFERENCES}

1. Kotarski J, Heczko PB, Lauterbach R, Niemiec T, Leszczyńska-Gorzelak B. Rekomendacje Polskiego Towarzystwa Ginekologicznego dotyczące wykrywania nosicielstwa paciorkowców grupy B (GBS) u kobiet w ciąży i zapobiegania zakażeniom u noworodków. Ginekol Pol 2008;79: 221-3. 
2. Perinatal group B streptococcal disease after universal screening recommendations - United States, 2003-2005. MMWR 2007;56(28):701-5.

3. Falciglia G, Hageman JR, Schreiber M, Alexander K. Antibiotic therapy and early onset sepsis. Neo Rev 2012:13(2):e86.

4. Kraśnianin E, Skręt-Magierło J, Witalis J, Barnaś E, Kluz T, Kozieł A, et al. The incidence of Streptococcus group B in 100 parturient women and the transmission of pathogens to the newborn. Ginekol Pol 2009;80:285-9.

5. Barcaite E, Bartusevicius A, Tameliene R, Kliucinskas M, Maleckiene L, Nadisauskiene R. Prevalence of maternal group B streptococcal colonisation in European countries. Acta Obstet Gynecol Scand 2008;87: 260-71.

6. Matsubara K, Yamamoto G. Invasive group B streptococcal infections in a tertiary care hospital between 1998 and 2007 in Japan. Int J Infect Dis 2009;13:679-84.

7. Nomura ML, Passini Júnior R, Oliveira UM, Calil R. Group B streptococcus maternal and neonatal colonization in preterm rupture of membranes and preterm labor. Rev Bras Ginecol Obstet 2009;31(8):397-403.

8. Seoud M, Nassar AH, Zalloua P, Boghossian N, Ezeddine N, Fakhoury H. Prenatal and neonatal Group B Streptococcus screening and serotyping in Lebanon: incidence and implications. Acta Obstet Gynecol Scand 2010;89:399-403.

9. Simetka O, Petros M, Podesvová H. Prevention of early-onset neonatal group B streptococcal infection: neonatal outcome after introduction of national screening guideline. Ceska Gynekol 2010;75:41-6.

10. Valkenburg-van den Berg AW, Houtman-Roelofsen RL, Oostvogel PM, Dekker FW, Dörr PJ, Sprij AJ. Timing of group B streptococcus screening in pregnancy: a systematic review. Gynecol Obstet Invest 2010;69:174-183.

11. Kociszewska-Najman B, Oslislo A, Szymusik I, Pietrzak B, Jabiry-Zieniewicz Z. Śródporodowa profilaktyka zakażeń paciorkowcami grupy B doświadczenia własne. Ginekol Pol 2010;81:913-7.

12. Dobrowolska-Redo A, Romejko-Wolniewicz E, Zaręba-Szczudlik J, Czajkowski K. Porównanie przebiegu porodu, wczesnego połogu i okresu noworodkowego w zależności od flory bakteryjnej obecnej w wymazie z dróg rodnych. Perinatol Neonatol Ginekol 2013;6:73-80.

13. Glasgow TS, Speakman M, Firth S, James B, Byington CL, Young PC. Clinical and economic outcomes for term infants associated with increasing administration of antibiotics to their mothers. Paediatr Perinat Epidemiol 2007;21:338-46 